\title{
How Does a Security Frame Affect Support for Refugee Protection in France and Germany in the Aftermath of Europe's Refugee Crisis?
}

\author{
Melissa Schnyder
}

\begin{abstract}
This article examines whether public support for the protection of refugees in France and Germany changes when refugee protection is framed as a national security matter. In focusing on public attitudes four years after the height of Europe's refugee crisis, the paper examines two competing theoretical predictions: (a) that support for refugees should decrease when the matter is framed in terms of security, and (b) that sustained intergroup contact over time should decrease prejudice toward out-groups. Using a survey experiment design, research participants in France and Germany were randomly assigned into either a treatment or control group. The treatment group was exposed to a security frame, whereas the control groups did not see a frame. The experiment shows no evidence that a security frame has an overall effect on opinions about refugee protection, suggesting that this issue frame may not generate significant framing effects in these two countries, which have settled a large percentage of refugees and have had time for intergroup contact. The conclusion contextualizes these findings and presents avenues for future research on issue framing.
\end{abstract}

Keywords: Refugee protection, securitization, out-groups, tolerance, issue frames, Europe

\section{¿Cómo afecta un marco de seguridad al apoyo a la protección de los refugiados en Francia y Alemania después de la crisis de refugiados en Europa?}

\section{RESUMEN}

Este artículo examina si el apoyo público a la protección de los refugiados en Francia y Alemania cambia cuando la protección de los refugiados se enmarca como un asunto de seguridad nacional. Al centrarse en las actitudes del público cuatro años después del apogeo de la crisis de refugiados en Europa, el documento examina dos 
predicciones teóricas en competencia: (a) que el apoyo a los refugiados debería disminuir cuando el asunto se enmarca en términos de seguridad, y (b) que el contacto intergrupal sostenido con el tiempo debería disminuir el prejuicio hacia los grupos externos. Utilizando un diseño de experimento de encuesta, los participantes de la investigación en Francia y Alemania fueron asignados al azar a un grupo de tratamiento o de control. El grupo de tratamiento estuvo expuesto a un marco de seguridad, mientras que los grupos de control no vieron un marco. El experimento no muestra evidencia de que un marco de seguridad tenga un efecto general en las opiniones sobre la protección de los refugiados, lo que sugiere que este marco temático puede no generar efectos de marco significativos en estos dos países, que han asentado a un gran porcentaje de refugiados y han tenido tiempo para el contacto intergrupal. La conclusión contextualiza estos hallazgos y presenta avenidas para futuras investigaciones sobre el encuadre de problemas.

Palabras clave: Protección de refugiados, titulización, grupos externos, tolerancia, marcos temáticos, Europa

\section{欧洲难民危机后的安全框架如何影响法 国和德国公众对难民保护的支持}

摘要

本文研究了当难民保护被建构为一个国家安全事务时, 法国 和德国公众对难民保护的支持是否会发生变化。聚焦欧洲难 民危机爆发后第四年的公众态度，本文分析了两个不同的理 论预测：（a）当难民事务被建构为安全事务时公众支持应 会下降，（b）持续的群体间接触（intergroup contact）会 随时间推移而降低对外群的偏见。通过使用一项调查实验设 计, 两国的研究参与者被随机分配到实验组或对照组。实验 组被暴露在难民保护这一安全框架下，对照组则没有。实验 表明, 没有证据证明安全框架对难民保护與论产生了整体效 果, 这暗示该议题框架可能不会在法国和德国产生显著的框 架效应, 两国已经安置了大量难民并为群体间接触提供了时 间。结论将研究发现情境化, 并就议题框架的未来研究提供 了方法。

关键词: 难民保护, 安全化, 外群, 容忍, 议题框架, 欧洲 


\section{Introduction}

$\mathrm{R}$ esearch examining the politics of issue framing and its institutionattitudes toward immigration and asylum are shaped in fundamental ways by how government elites and the media present the issue. In the issue framing literature, the security frame has been the focus of much research, examining how positioning the issue of migration as a security threat impacts public perceptions and opinions (Huysmans, 2000; Bourbeau, 2011; Mountz, 2015). Some studies have shown that a security frame produces more restrictive policy outcomes and attitudes toward migration among mass publics (Lahav and Courtemanche, 2012; Koslowski, 2002). However, other research has shown that publics are more tolerant than is often assumed. For example, political tolerance research has shown that living alongside members of a perceived "out group" can increase tolerance over time (Allport, 1955). Moreover, the content and character of public opinion appears to vary across space and time, generating fundamental debates about the extent to which publics hold restrictive versus more tolerant attitudes toward immigration and asylum, and the degree to which those (seemingly volatile) opinions inform policy (Freeman et al., 2012). Some studies, for example, have highlighted negative media portrayals of migrants and refugees in terms of security and economic threats (Greussing and Boomgaarden, 2017), and have examined how negative perceptions influence attitudes toward migration (May- da and Facchini, 2006; Hansen, 2007). In general, much of this research documents the volatility of public opinion, highlighting dramatic fluctuations in attitudes toward migrants and refugees depending upon the question wording used and the level of detail presented in the frame itself (Schildkraut, 2013). Simply put, "there is still no consensus regarding the scope, definition, and impact of security as it relates to migration practices" (Lahav 2013, 237, citations omitted). Overall, this suggests that the security frame may not resonate particularly well in certain places or times. To help inform this debate, this research examines the extent to which a security frame impacts public opinion about refugees in Europe several years after the height of Europe's refugee crisis. Does a security frame still resonate with the general public in refugee-receiving countries four years after the height of the refugee crisis, or has intergroup contact subdued its impact over time in countries that have settled a large percentage of refugees?

Taking this question as the point of departure, this study aims to test the effect of a security frame on public support for refugee protection policy in France and Germany-two countries that have taken in a large number of refugees during Europe's refugee crisis. To examine how the framing of refugee protection as a security issue affects public opinion about refugee protection policy, this research uses an experimental approach. Survey experiments in France and Germany focus on testing an issue frame that positions refugee protection in the context of national se- 
curity concerns. A battery of questions is used to measure support in order to guard against effects that are simply a function of the way a single question is worded. The security frame has been identified in the literature on forced displacement and migration, and is reflected in media and political discourse. If the security frame produces a framing effect in the post-refugee crisis period, then we should observe a decrease in public support for the protection of refugees relative to the control group. On the other hand, the intergroup contact hypothesis predicts that meaningful contact over a sustained period of time between refugees and their host populations should decrease prejudice, potentially rendering the security frame ineffective. This paper investigates these two predictions. The following section provides a more thorough discussion of the literature, followed by a description of the survey experiment methodology and data. After this, the results are presented along with a discussion. Lastly, the conclusion contextualizes the results of this study in light of the literature and develops implications for assessing public opinion on the issue. This paper contributes to the issue framing literature, as well as the extensive literature on the securitization of migration and refugee politics. It adds to the literature by considering the impact of a security frame not during the height of a crisis period, but several years later, after meaningful intergroup contact between in- and out-groups has had a chance to occur.

\section{Issue Framing, Migration \\ Securitization, and Intergroup Contact}

$n$ issue frame is a specific way
of presenting information in
which the messenger emphasizes certain aspects of an issue, thereby highlighting specific dimensions of the issue that are in-frame and omitting other dimensions that remain out-offrame (Snow, 2013). Thus, issue framing can significantly affect how people process information. For any particular issue, advocates use in-frame dimensions to construct a specific narrative and communicate it to a target audience. Through this process of framing, the way that a particular issue or aspect of a problem is perceived and understood becomes redefined (Snow, 2013). Framing, then, through "meaning construction" (Snow, 2013, 470), allows advocates to create a collective interpretation of a problem or issue. The act of constructing meaning involves focusing on the cause of the problem, offering solutions, and mobilizing supporters to participate in common actions to effect a desired change. Those involved with the issue can therefore use issue frames as a means of creating consensus regarding both the nature of a problem and the types of solutions needed to resolve it, and can motivate supporters into action in the specific ways suggested by the frame (Benford and Snow, 2000; Snow, 2013). There is strong evidence in the issue framing literature to show that public opinion changes based on how an issue is presented (Chong and Druckman, 2007; Jacoby, 2000; 
Berinsky and Kinder, 2006; Krosnick and Kinder, 1990). Moreover, because public opinion influences policymaking (Stimson et al., 1995; Soroka and Wlezien, 2010), the way that a particular issue is framed can also profoundly impact the policy responses to that issue (Keohane, 2015).

Over the years, migration has become a securitized policy space (Bourbeau, 2011), and much research has examined the securitization of migration in different political and institutional contexts (Bourbeau, 2011; Ceyhan and Tsoukala, 2002; Gerard, 2014; Mountz, 2015; Lazaridis and Skleparis, 2015). Across the last four decades in Western Europe, the political discourse as it relates to migration has progressively focused on its perceived destabilizing effects on domestic society and has linked it to security issues, including dangers for public order (Huysmans, 2000). Many and varied challenges to the nation-state, to include "economic and financial globalization, the rise of poverty, the deterioration of living conditions in cities, the revival of racist and xenophobic parties and movements, the estrangement of the electorate from the political class, and the rise of multiculturalism" (Huysmans, 2000, 752) have contextualized the social construction of migration into a national security issue. These issues and processes have played out over time such that any type of migration (including asylum) is framed and discussed as a phenomenon that erodes a singular conception of national and cultural identity, while compromising public order and economic stability (Ugur, 1995;
Doty, 1996). Additionally, as migration becomes increasingly politicized and securitized, the institutionally separate tracks of economic migration and asylum become linked in public and political discourse, and asylum is sometimes (mis)constructed as an alternate means of pursuing economic migration to the EU (den Boer, 1995). These developments have contributed to the issue of refugee protection increasingly being framed as a security matter. Within the $\mathrm{EU}$, regulations on migration are debated and created within an institutional framework that emphasizes internal security and its protection (Buzan et al., 1998). In this context, public discourse that links asylum to criminal networks and terrorism further politicizes and securitizes the issue. In sum, these dynamics together lead to the framing of immigration and asylum as a security matter in political and policy discourse, as opposed to framing them as economic or human rights matters, for example.

The process of framing migration as a matter of national security involves many actors, including the media, governments, and professional security networks. Some research suggests that restrictive policies have institutionalized public consensus, as migration policy has become more security-oriented over time (Lahav and Guiraudon, 2006), and particularly so since the height of Europe's refugee crisis in 2015. In this view, securitization has become "mainstreamed" into the political agenda (Collett and Le Coz, 2018). Many studies have shown how governments have tied the issues of migration and 
asylum to law and order, and security more broadly, at the national, regional, and international levels (Lavenex and Ucarer, 2002; Lahav, 2003). Thus, as political actors publicly associate migration with physical threats, such as crime and terrorism, we might expect to observe more restrictive policy preferences among the public and more protectionist attitudes concerning border control (Lahav et al., 2007; Lahav and Courtemanche, 2012). There is also some evidence that public preferences influence policy outcomes, as relatively recent changes toward more restrictive migration policies in Europe can be seen as a reflection of changing preferences among both the masses and political elites (Lahav, 2004). In general, prior research has found that a security frame that presents migrants as physical threats (as opposed to cultural threats) has some impact on public attitudes and preferences (Lahav and Courtemanche, 2012). The literature on social psychology and political behavior provides much evidence to show that political elites' attitudes and public opinion regarding migration are influenced, often to a large degree, by perceptions of threat. In addition to physical threats, the literature has examined how frames that emphasize threats to national security and identity are associated with intolerance toward migrants (Lahav, 2004; McLaren, 2003). Security framing that emphasizes various dimensions of threat increases xenophobic attitudes, ethnocentrism, and in-group cohesion, promoting intolerance (Huddy, 2001; Levine and Campbell, 1972). More- over, research has documented how a heightened appraisal of risk leads to greater support for policies that curtail the rights of out-groups (Branton and Jones, 2005; Coenders et al., 2009), and result in citizens being more willing to compromise democratic values and personal freedoms and liberties (Davis and Silver, 2004; Mutz et al., 1996).

On the other hand, the political tolerance literature offers a different prediction, suggesting that public opinion toward migrants might be more favorable than is often assumed by the securitization literature. Some research, for example, has shown that public attitudes become more favorable when individuals are presented with and informed about some of the complexity surrounding immigration (Freeman et al., 2012), suggesting that the scope of information presented and framing both matter. In addition, contact theory suggests that intercultural exposure should, over time, increase levels of political tolerance toward migrants and other out-groups perceived as culturally different (Allport 1955-see APSR article). The contact hypothesis posits that intergroup contact can significantly reduce prejudice toward out-groups. This hypothesis holds implications for how persuasive a security frame can ultimately be with the general public. Here, however, the type of contact matters. Meaningful intergroup contact (that is, contact that is sustained, has a common objective in mind, and is cooperative) has been shown to reduce negative sentiments, whereas superficial or "casual" contact may actually increase prejudice (Allport, 1955). This line of research 
finds that attitudes often become more favorable as people gain experience living alongside, and interacting with, migrants and ethnic minorities (Freitag and Rapp, 2013), as meaningful contact has a chance to take hold and develop. For example, using a field experiment, Finseraas et al. (2019) randomly assigned Norwegian soldiers to share rooms with ethnic minorities, and found that repeated intergroup contact led to higher levels of trust toward immigrants. Similarly, Steinmayr (2020) has demonstrated an increase in support for the Freedom Party of Austria (Austria's far-right party) in areas where refugees were only passing through in 2015 (in other words, where there was only superficial contact), compared to lower levels of support for the far-right party in areas that hosted refugees for a sustained period of time. These findings could lead one to expect that a security frame would not significantly reduce public support for refugee protection in France and Germany, since both countries hosted sizable numbers of refugees during and after the 2015 refugee crisis, unlike, for example, many Eastern European states which were more likely to be transit countries for migrants and refugees and not final destinations. Overall, meaningful intergroup contact provides opportunities to share experiences over time and to build trust. This mechanism is further confirmed by Pettigrew and Tropp's (2006) meta-analysis in which they examined over 500 studies and concluded that the evidence supports the claim that intergroup contact generally reduces prejudice. In this respect, repetitive contact with cultur- ally different groups should moderate hostility toward those groups.

\section{Experimental Protocol}

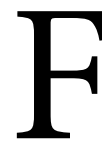
Trom June through August 2019, individuals over the age of 18 years in France and Germany were recruited to an online survey experiment to test their reactions to a security frame using Amazon's Mechanical Turk (MTurk). France and Germany were selected based on several factors. To begin, both were among the member countries of the EU which had the highest number of asylum applicants granted protection status in 2015, the height of Europe's refugee crisis $(\mathrm{Eu}-$ rostat, 2016). An elapsed time of four years since the height of the refugee crisis should have provided many residents with opportunities to engage and interact with settled asylum-seekers, which, according to the contact hypothesis, would be needed for building tolerance and trust. In addition, one can also observe opposition to refugee protection and general migration in France and Germany, mainly via the positions of the far-right political parties. For instance, Germany's far-right Alternative for Germany party has recently fared well in the former Communist East (Bennhold and Eddy, 2019), and in 2015 the far-right political party in France (Rassemblement National, formerly Front National) won $28 \%$ of the vote, and won in the first round of its 2017 presidential elections (European Election Database, 2017). This suggests that a security frame may nonetheless resonate with certain segments of the 
population, even as asylum-seekers integrate into society. Each country thus presents an interesting case for testing whether a security frame still holds salience when presented to the general population in the aftermath of the 2015 refugee crisis.

MTurk data generates valid estimates of treatment effects, as has been shown in prior studies (Berinsky et al., 2012; Goodman et al., 2013). Although MTurk samples are not representative, they are generally more reflective of the general population compared to other convenience samples (Berinsky et al., 2012; Goodman et al., 2013; Huff and Tingley, 2015). Therefore, while the use of MTurk data does not harm internal validity, it does affect the ability to make external generalizations beyond the cases considered here.
Participants in this research were paid US\$1.50 each for their participation. Other studies have used MTurk to collect samples for as little as US\$0.10 (Goodman et al., 2013). In this survey experiment, participants were paid regardless of whether or not they fully completed the experiment. Consistent with experimental protocol, each individual was randomly assigned to a control group or to a treatment group in which they were asked to read a paragraph that framed the issue of refugee protection in that country as a security threat. The security frame paragraph is presented in Table 1. After viewing the security frame, participants were then asked to complete a short questionnaire. ${ }^{1}$ The control group did not see any frame. This group was simply routed directly to the short questionnaire.

Table 1. Text of Security Frame

\section{Security Frame}

A refugee is someone who has been forced to escape his or her country because of war, or because they are being threatened with extreme violence, death, or other types of inhumane treatment in their own country.

By allowing a mass migration of refugees, particularly those from places where religious or political violence is widespread, countries open themselves up to possible threats. Often, governments cannot perform proper screening or background checks on these refugees, so they may not be able to distinguish legitimate refugees from terrorists. Not all people who are escaping dangerous situations are innocent victims. Many are simply on the losing end of bloody ethnic and religious conflicts. The challenge to refugee policy is, given the complete chaos in the sending countries, to be able to sort out the innocent people from those who may have ulterior motives.

Note: Respondents were randomly assigned to the treatment frame $(\mathrm{n}=39)$. The control group $(\mathrm{n}=46)$ did not see a frame.

1 The dependent variable questions from the questionnaire are included in the appendix. 
Before reading the security frame paragraph and answering the survey questions, all participants provided consent online, which is a stipulation of the study's IRB protocol. In addition, prior to taking part in the research study, participants were shown a description of what the experiment would involve, the estimated time for completion, and compensation details. Upon providing consent, participants were given the opportunity to click on a link to proceed to the survey experiment.

The treatment group consists of 39 respondents and the control group has 46 respondents. As a guide, Roscoe (1975) proposes the rules of thumb (as cited in Sekaran and Bougie, 2010: 296297) concerning minimal sample sizes per group of 30 as appropriate. In this study, a minimum sample size of 35 is required for a minimum desired power of 0.72 and a $90 \%$ confidence interval (Brant, n.d.).

The survey questionnaire that all participants answered is used to measure three dependent variables. As a reminder, the treatment group answered the survey questionnaire after viewing the security frame paragraph, whereas the control group simply answered the questionnaire without viewing any frame at all. First, respondents were asked to provide a value from 0 to 10 to assess the importance of refugee protection policy, with zero representing no importance and ten representing very high importance. Because a respondent could assign a high absolute importance to refugee protection, but at the same time rank it low in comparison with other important issues, respondents were also asked to rank the relative importance of refugee protection compared to six other salient global issues: climate change, democratization, global public health, international economic policy, the spread of nuclear weapons, and terrorism. Several opinion polls informed the choice of these particular issues, including a Gallup poll (Riffkin, 2014), a Pew Research Center poll (Stokes, 2013), and the Eurobarometer survey (Eurobarometer, 2014). Finally, respondents were asked to assess the need to change refugee protection policy relative to the status quo situation in their country (per Sullivan and Rich, 2017) by reporting whether the number of refugees permitted to enter their respective country should increase, stay about the same, or decrease. Table 2 displays the summary statistics for each of these three dependent variables.

Table 2. Summary Statistics for Dependent Variables

\begin{tabular}{lcccc}
\hline & Mean & Std. Dev. & Min. & Max. \\
\hline $\begin{array}{l}\text { Rating, Importance of Refugee Protection } \\
\text { Ranking, Importance of Refugee Protection } \\
\text { (1=most important) }\end{array}$ & 7.38 & 2.13 & 0 & 10 \\
$\begin{array}{l}\text { Number of Refugees Should (1=decrease, } \\
\text { 2=stay about the same, 3=increase) }\end{array}$ & 2.01 & 0.75 & 1 & 7 \\
\hline
\end{tabular}

Source: Survey experiments. 


\section{The Security Frame: Effects on Public Support for Refugee Protection}

The effects of the security frame are examined using a differencein-means estimator, with the results reported in Table 3.

The first dependent variable examined here consists of a measurement of individuals' opinions regarding the importance of refugee protection in an absolute sense. Table 3 displays the mean rating of the absolute importance of refugee protection by the treatment group-those who saw a security frame. The treatment effect reflects the dif- ference in mean ratings relative to the control group, for which the mean rating of refugee protection importance on the $0-10$ scale is 7.50 . Overall, the security frame does not produce a statistically significant framing effect when examined in the context of this dependent variable. That is to say, the difference in the mean ratings between the treatment group and the control group is not big enough to produce a statistically significant effect. This lends some initial, if indirect, weight to the idea that exposure to an out-group over time can have moderating effects, which would lessen the impact that a security frame might otherwise have among the general population.

Table 3. Security Frame and Ratings of Support for Refugee Protection Policy

\begin{tabular}{lcccc}
\hline & $\begin{array}{c}\text { Estimated } \\
\text { Treatment } \\
\text { Effect }\end{array}$ & $\begin{array}{c}\text { Mean } \\
\text { Score }\end{array}$ & $\begin{array}{c}\text { Two- } \\
\text { Tailed } \\
p \text {-value }\end{array}$ & $\begin{array}{c}\text { 95\% } \\
\text { Confidence } \\
\text { Interval }\end{array}$ \\
\hline $\begin{array}{l}\text { DV: Importance of Refugee } \\
\text { Protection } \\
\text { Security Frame }\end{array}$ & -0.244 & 7.26 & 0.607 & $1.165,0.685$ \\
\hline $\begin{array}{l}\text { DV: } \text { Ranking of Refugee } \\
\begin{array}{l}\text { Protection } \\
\text { Security Frame }\end{array}\end{array}$ & 0.431 & 4.69 & 0.208 & $0.244,1.104$ \\
\hline $\begin{array}{l}\text { DV: } \text { Number of Refugees } \\
\text { Should Increase or Stay the } \\
\text { Same } \\
\text { Security Frame }\end{array}$ & & & & \\
\hline
\end{tabular}

Note: Estimated treatment effects represent differences in mean scores relative to the control group. Source: Data from survey experiments.

The second dependent variable reflects the relative importance of refugee protection policy, for which re- spondents were asked to rank refugee protection importance relative to six other salient global issues, ranging from 
1 (most important) to 7 (least important). Table 3 displays the difference in the mean ranking of the importance of refugee protection for the security frame treatment group relative to the control group. For comparison purposes, the mean ranking of refugee protection in the control group is 4.26 . Similar to results discussed above, here there is not a statistically significant framing effect. In other words, there is no statistically significant difference between the treatment group, which saw the security frame, and the control group, which did not, on their mean rankings of the relative importance of refugee protection. Similar to the above finding, this result suggests that four years post the height of the refugee crisis might be enough time to moderate out-group differences. Over the course of the past four years, intergroup contact would have taken place between the native population and refugees. According to the contact hypothesis, this intergroup contact would be expected to dampen any effect that a security frame might have on local attitudes toward refugees in these countries.

The third and final dependent variable asks respondents whether the number of refugees allowed to enter their country should decrease, stay about the same, or increase, and thus presents a more specific attitudinal measure compared to the "importance" questions of the first two dependent variables. In order to more precisely hone in on those who believe that refugee protection policy should become more stringent or restrictive versus those who do not, the variable was recoded such that zero reflects a belief that the overall numbers should decrease, whereas 1 indicates a belief reflecting no change or an increase. Table 3 displays the mean rating for the security frame treatment group, which again is considered relative to the control group, whose mean level of support on this question is 0.67 . As with the above two dependent variables, there is no evidence of a framing effect, as the treatment group's mean score is not statistically different from the control group's mean score. Thus, there is a consistent lack of evidence for a framing effect across the three dependent variables tested here.

Taken together, these results do not provide evidence of a statistically significant framing effect when respondents are exposed to a frame that positions refugees as a security issue. At the same time, while they do not provide direct evidence of tolerance as a result of the contact hypothesis, these null findings are nonetheless more consistent with the tolerance literature, which argues that exposure to a particular out-group over time should lessen views that perceive that out-group as a threat. These experiments do not find strong enough support to suggest that framing refugee protection as a matter of security in Germany and France alters support for refugee protection or perceptions of its importance as a policy issue. At the same time, however, these null findings do not necessarily indicate that the security frame has no effect; they only indicate that we cannot conclude that there is, in fact, a treatment effect. Although the null findings suggest indirect support for the toler- 
ance literature, the experiments cannot definitively conclude that there is no framing effect (Gill, 1999). Future research is needed to add more evidence to these initial findings.

\section{Conclusion}

$\mathrm{U}$ sing survey experiments administered to the general public in France and Germany, this paper focused on the extent to which positioning refugee protection as a national security threat produces a framing effect that impacts public attitudes toward refugee protection policy. The analysis finds that several years after the peak of Europe's refugee crisis, the security frame does not significantly alter public support for the protection of refugees in France and Germany, regardless of whether support is measured in a specific way by asking about admitting more or fewer refugees into the country, or whether it is measured in more general terms concerning the importance of the issue. These null findings are consistent with other research that finds that as the population interacts with and encounters a specific out-group with increasing frequency, the perceived threat of that particular out-group decreases over time (Allport, 1955). Experimental public opinion studies such as this can be used to determine the influence of different kinds of frames on public opinion over time, and policy designers can use this type of information to decide on appropriate policies or policy changes at different points in time, as public opinion changes.
The security frame used in these experiments linked the refugee issue to an increased risk of terrorism, reflecting themes found in many public debates, the media, and some political elites, and also presented the issue in terms of the more general risk of opening the country to an increased threat of violence. Because prior research confirms that it is more difficult for people to evaluate psychologically abstract concepts as opposed to more concrete concepts (Liberman et al., 2007; Trope and Liberman, 2003), the presentation of the issue in terms of general threats to national security could possibly decrease the perceived importance that individuals assign to refugee protection policy. Other research examining security frames suggests that frames that position the issue as a more concrete physical threat may have particularly strong effects on public opinion and decrease support for upholding states' obligations to provide international protection to those who have been forcibly displaced (Lahav and Courtemanche, 2012). Thus, one area for future research is to create and test different types of frames applied to the issue of refugee protection. It would also be worthwhile to test such frames at different points in time, before, during, and after periods of crisis, for example, to get a better sense of how public opinion changes over time.

Recent research has shown that Europeans' attitudes concerning the protection of refugees and asylum seekers are typically more tolerant than many politicians and the media tend to assume; moreover, these attitudes 
tend to be very consistent across different European countries (Jeannet et al., 2019). Individuals' support for refugee protection policy is thus not as rigid as is often assumed and may not be consistently amenable to rhetoric that securitizes the issue, particularly as time passes after a major shock. This possibility is important to consider, as Hochschild and Einstein (2015) under- score how misinformation about public opinion and public policy preferences can produce bad policies. For scholars who study tolerance, the results of this study point to a greater need to examine how public attitudes may shift over time as meaningful exposure to outgroups increases, particularly after the shock of crises or other major global events subsides.

\begin{abstract}
Melissa Schnyder holds a Ph.D. in Political Science, and is Professor of Global Security at American Public University and Co-Director of the Multidisciplinary Research Council. A former Fulbright Fellow to the European Union, her research examines the role of NGOs and other civil society actors in creating norm-driven policy change in a myriad of human security policy issues (forced displacement, statelessness, climate change, environmental sustainability, food security).
\end{abstract}

\title{
References
}

Allport, Gordon W. (1955). The Nature of Prejudice. Cambridge, MA: AddisonWesley.

Benford, Robert D., and David A. Snow. (2000). "Framing Processes and Social Movements: An Overview and Assessment." Annual Review of Sociology 26: 611639.

Bennhold, Katrin, and Melissa Eddy. (2019). "Election in Germany Helps Far Right Tighten Its Grip in the East." The New York Times, 27 October 2019. https://www. nytimes.com/2019/10/27/world/europe/germany-election-afd-thuringia.html.

Berinsky, Adam J., Gregory A. Huber, and Gabriel S. Lenz. (2012). "Evaluating Online Labor Markets for Experimental Research: Amazon.Com's Mechanical Turk." Political Analysis 20(3): 351-368. https://doi.org/10.1093/pan/mpr057.

Berinsky, Adam J., and Donald R. Kinder. (2006). "Making Sense of Issues Through Media Frames: Understanding the Kosovo Crisis." Journal of Politics 68(3): 640656. 
Bourbeau, Philippe. (2011). The Securitization of Migration: A Study of Movement and Order. New York: Routledge.

Brant, Rollin. n.d. "Inference for Means: Comparing Two Independent Samples." Accessed 1 February 2020. https://www.stat.ubc.ca/ rollin/stats/ssize/n2.html.

Branton, Regina P., and Bradford S. Jones. (2005). "Reexamining Racial Attitudes: The Conditional Relationship Between Diversity and Socioeconomic Environment." American Journal of Political Science 49(2): 359-372. https://doi.org/ 10.1111/j.0092-5853.2005.00128.x

Buzan, Barry, Jaap de Wilde, and Ole Wæver. (1998). Security: A New Framework for Analysis. Boulder, CO: Lynne Rienner.

Ceyhan, Ayse, and Anastassia Tsoukala. (2002). "The Securitization of Migration in Western Societies: Ambivalent Discourses and Policies." Alternatives 27(1) suppl: 21-39. https://doi.org/10.1177/03043754020270S103.

Chong, Dennis, and James N. Druckman. (2007). "Framing Public Opinion in Competitive Democracies." American Political Science Review 101(4): 637-655.

Coenders, Marcel, Marcel Lubbers, and Peer Scheepers. (2009). “Opposition to Civil Rights for Legal Migrants in Central and Eastern Europe: Cross-national Comparisons and Explanations." East European Politics and Societies 23(2): 146164. https://doi.org/10.1177/0888325408327847.

Collett, Elizabeth and Camille Le Coz. (2018). After the Storm: Learning from the EU Response to the Migration Crisis. Brussels: Migration Policy Institute Europe.

Davis, Darren W., and Brian D. Silver. (2004). "Civil Liberties vs. Security: Public Opinion in the Context of the Terrorist Attacks on America." American Journal of Political Science 48(2): 28-46.

den Boer, Monica. (1995). "Moving between Bonafide and Bogus: The Policing of Inclusion and Exclusion in Europe." In Migration and the European Integration, edited by Dietrich Thränhardt and Robert Miles, 92-111. London: Pinter Publishers.

Doty, Roxanne Lynn. (1996). "Immigration and National Identity: Constructing the Nation." Review of International Studies 22(3): 235-255.

Eurobarometer. (2014). Special Eurobarometer 379. Accessed 7 January 2020. https://data.europa.eu/euodp/en/data/dataset/S1059_76_4_EBS379. 
European Election Database. (2017). Country Tables. Accessed 18 October 2017. http://www.nsd.uib.no/european_election_database.

Eurostat. (2016). "Asylum Decisions in the EU. EU Member States Granted Protection to More Than 330,000 Asylum Seekers in 2015. Half of the Beneficiaries were Syrians." Accessed 30 August 2020. http://ec.europa.eu/eurostat/ documents/2995521/7233417/3-20042016-AP-EN.pdf/34c4f5af-eb93-4ecd-984c$577 \mathrm{a} 5271 \mathrm{c} 8 \mathrm{c} 5$.

Finseraas, Henning, Torbjørn Hanson, Åshild A. Johnsen, Andreas Kotsadam, and Gaute Torsvik. (2019). "Trust, Ethnic Diversity, and Personal Contact: A Field Experiment.” CESifo Working Paper Series 7515, CESifo.

Freeman, Gary P., Randall Hansen, and David L. Leal (eds.). (2012). Immigration and Public Opinion in Liberal Democracies. Abingdon: Routledge.

Freitag, Markus, and Carolin Rapp. (2013). "Intolerance Toward Immigrants in Switzerland: Diminished Threat Through Social Contacts?” Swiss Political Science Review 19(4): 425-446. https://doi.org/10.1111/spsr.12049.

Gerard, Alison. (2014). The Securitization of Migration and Refugee Women. New York: Routledge.

Gill, Jeff. (1999). “The Insignificance of Null Hypothesis Significance Testing.” Political Research Quarterly 52(3): 647-674.

Goodman, Joseph K., Cynthia E. Cryder, and Amar Cheema. (2013). "Data Collection in a Flat World: The Strengths and Weaknesses of Mechanical Turk Samples." Journal of Behavioral Decision Making 26(3): 213-224. https://doi.org/ 10.1002/bdm.1753.

Greussing, Esther, and Hajo G. Boomgaarden. (2017). "Shifting the Refugee Narrative? An Automated Frame Analysis of Europe's 2015 Refugee Crisis." Journal of Ethnic and Migration Studies 43(11): 1749-1774.

Hansen, Randall. (2007). "Migration Policy." In European Politics, edited by Colin Hay and Anand Menon, 329-345. Oxford: Oxford University Press.

Hochschild, Jennifer, and Katherine Levine Einstein. (2015). “It Isn't What We Don't Know that Gives Us Trouble, It's What We Know that Ain't So': Misinformation and Democratic Politics." British Journal of Political Science 45(3): 467-475. https:// doi.org/10.1017/S000712341400043X. 
Huddy, Leonie. (2001). "From Social to Political Identity: A Critical Examination of Social Identity Theory." Political Psychology 22: 127-156.

Huff, Connor, and Dustin Tingley. (2015). “'Who are These People?' Evaluating the Demographic Characteristics and Political Preferences of MTurk Survey Respondents." Research \& Politics 2(3): 1-12. https://doi.org/10.1177/205316801 5604648 .

Huysmans, Jef. (2000). “The European Union and the Securitization of Migration.” Journal of Common Market Studies 38: 751-777. https://doi.org/10.1111/14685965.00263.

Jacoby, William G. (2000). "Issue Framing and Public Opinion on Government Spending." American Journal of Political Science 44(4): 750-767.

Jeannet, Anne-Marie, Esther Ademmer, Martin Ruhs, and Tobias Stohr. (2019). "What Asylum and Refugee Policies do Europeans Want? Evidence from a Cross-national Conjoint Experiment." EUI RSCAS, 2019/73, Migration Policy Centre. https://cadmus.eui.eu/handle/1814/64384.

Keohane, Robert O. (2015). "The Global Politics of Climate Change: Challenge for Political Science." PS: Political Science \& Politics 48(1): 19-26.

Koslowski, Rey. (2002). "Immigration, Border Control and Aging Societies in the European Union.” The Brown Journal of World Affairs 8(2): 169-180.

Krosnick, Jon A., and Donald R. Kinder. (1990). "Altering the Foundations of Support for the President Through Priming." American Political Science Review 84(2): 497-512.

Lahav, Gallya. (2003). "Migration and Security: The Role of Non-State Actors and Civil Liberties in Liberal Democracies." Paper prepared for the Second Coordination Meeting on International Migration, Department of Economic and Social Affairs, Population Division, UN, New York, 15-16 October 2003.

Lahav, Gallya. (2004). "Public Opinion Toward Immigrants in the European Union: Does It Matter?” Comparative Political Studies 37: 1151-1183.

Lahav, Gallya. (2013). “Threat and Immigration Attitudes in Liberal Democracies: The Role of Framing in Structuring Public Opinion.” In Immigration and Public Opinion in Liberal Democracies, edited by Gary P. Freeman, Randall Hansen, and David L. Leal, 232-253. Abingdon: Routledge. 
Lahav, Gallya, and Marie Courtemanche. (2012). "The Ideological Effects of Framing Threat on Immigration and Civil Liberties." Political Behavior 34(3): 477-505.

Lahav, Gallya, and Virginie Guiraudon. (2006). "Actors and Venues in Immigration Control: Closing the Gap between Political Demands and Policy Outcomes." West European Politics 29(2): 201-223. 10.1080/01402380500512551.

Lahav, Gallya, Anthony M. Messina, and Joseph Paul Vasquez. (2007). "The Immigration-Security Nexus: A View from the European Parliament.” In the EUSA Tenth Biennial International Conference, Montreal, Canada, May 17-19, available at www.unc.edu/euce/eusa2007/papers/lahav-g-08g.pdf.

Lavenex, Sandra, and Emek M. Uçarer, eds. (2002). Migration and the Externalities of European Integration. Lanham, MD: Lexington Books.

Lazaridis, Gabriella, and Dimitris Skleparis. (2016). "Securitization of Migration and the Far Right: the Case of Greek Security Professionals." International Migration 54(2): 176-192. https://doi.org/10.1111/imig.12219.

LeVine, Robert A., and Donald T. Campbell. (1972). Ethnocentrism: Theories of Conflict, Ethnic Attitudes, and Group Behavior. New York: John Wiley \& Sons.

Liberman, Nira, Yaacov Trope, Sean M. McCrea, and Steven J. Sherman. (2007). "The Effect of Level of Construal on the Temporal Distance of Activity Enactment." Journal of Experimental Social Psychology 43(1): 143-149. https://doi.org/ 10.1016/j.jesp.2005.12.009.

Mayda, Anna Maria, and Giovanni Facchini. (2006). Individual Attitudes Towards Immigrants: Welfare-State Determinants Across Countries. IZA Discussion Paper No. 2127, CESifo Working Paper Series No. 1768, IIIS Discussion Paper No. 143, Available at SSRN: https://ssrn.com/abstract $=902822$.

McLaren, Lauren M. (2003). "Anti-Immigrant Prejudice in Europe: Contact, Threat Perception, and Preferences for the Exclusion of Migrants." Social Forces 81(3): 909-36. http://www.jstor.org/stable/3598180.

Mountz, Alison. (2015). “in/Visibility and the Securitization of Migration: Shaping Publics through Border Enforcement on Islands." Cultural Politics 11(2): 184-200. doi: https://doi.org/10.1215.

Mutz, Diana Carole, Paul M. Sniderman, and Richard A. Brody. (1996). Political Persuasion and Attitude Change. Ann Arbor: University of Michigan Press. 
Pettigrew, Thomas F., and Linda R. Tropp. (2006). "A Meta-Analytic Test of Intergroup Contact Theory.” Journal of Personality and Social Psychology 90(5): 751783. https://doi.org/10.1037/0022-3514.90.5.751

Riffkin, Rebecca. (2014). "Unemployment Rises to Top Problem in the U.S." Accessed 4 January 2020. http://www.gallup.com/poll/167450/unemployment-risestop-problem.aspx.

Roscoe, John T. (1975). Fundamental Research Statistics for the Behavioral Sciences. New York: Holt, Rinehart, and Winston.

Schildkraut, Deborah J. (2013). “Amnesty, Guest Workers, Fences! Oh My! Public Opinion about 'Comprehensive Immigration Reform." In Immigration and Public Opinion in Liberal Democracies, edited by Gary P. Freeman, Randall Hansen, and David L. Leal, 207-231. Abingdon: Routledge.

Snow, David A. (2013). "Framing and Social Movements." In The Wiley-Blackwell Encyclopedia of Social and Political Movements, edited by David A. Snow, Donatella della Porta, Bert Klandermans, and Doug McAdam, 470-474. Malden, MA: Wiley-Blackwell.

Soroka, Stuart N., and Christopher Wlezien. (2010). Degrees of Democracy: Politics, Public Opinion and Policy. Cambridge: Cambridge University Press.

Steinmayr, Andreas. (2020). "Contact versus Exposure: Refugee Presence and Voting for the Far-Right." Review of Economics and Statistics 1-47.

Stimson, James A., Michael B. Mackuen, and Robert S. Erikson. (1995). "Dynamic Representation." American Political Science Review 89(3): 543-565.

Stokes, Bruce. (2013). “Americans' Foreign Policy Priorities for 2014." Accessed 3 January 2020. http://www.pewresearch.org/fact-tank/2013/12/31/americansforeign-policy-priorities-for-2014/.

Sullivan, Maggie, and Timothy S. Rich. (2017). "Many Refugees are Women and Children. That Changes whether Americans Want to Admit Them." The Washington Post, Monkey Cage, 29 November 2017. https://www.washingtonpost.com/ news/monkey-cage/wp/2017/11/29/americans-like-refugees-better-when-they re-women-and-children-especially-republicans/.

Trope, Yaacov, and Nira Liberman. (2003). “Temporal Construal.” Psychological Review 110(3): 403421. https://doi.org/10.1037/0033-295X.110.3.403. 
Ugur, Mehmet. (1995). "Freedom of Movement vs. Exclusion: A Reinterpretation of the 'Insider'-'Outsider' Divide in the European Union." International Migration Review 29(4): 964-999. 


\section{Appendix}

\section{Dependent Variable Survey Questions}

Should the number of refugees allowed to enter your country decrease, stay about the same, or increase?

$1=$ Decrease

$2=$ Stay about the same

$3=$ Increase

As a policy issue, how important is the protection of refugees, where 0 means not important at all and 10 means very important?

(Not important at all) 012345678910 (Extremely important)

Rank the following policy issues in order of importance from 1 (most important) to 7 (least important):

Listed in alphabetical order:

_ Climate change

_ Democratization

__ Global public health

__ International economic policy

_ Protection of refugees

_ Spread of nuclear weapons

_ Terrorism 